18. Арзуманова E.M. Стратиграфическое и географическое распространение позднемеловых иноцерамид Туркмении // Вопросы биостратиграфии и геологии полезных ископаемых Туркменистана. Ашхабад, 1973. С. 3-15.

19. Hancock J.M., Gale A.S. et al. The Campanian Stage // Bull. de L'Royal des Sciences Naturelles de Belgique,
Sciences de la Terre. Brussel, 1996. 66-Supp. P. 103-109. 20. Пергамент М.A. История изучения иноцерамов как руководящей фауны позднего мела (1814-1960) // Материалы III и IV Всесоюз. коллоквиумов. М., 1978. С. 30-68.

21. Пергамент М.A. Стратиграфия и иноцерамы верхнего мела Северного полушария. М., 1978. 191 с.

УДК 551.782 .2 (470.45)

\title{
НАДСОЛЕВЫЕ МЕЗОЗОЙСКО-КАЙНОЗОЙСКИЕ ОТЛОЖЕНИЯ ГРЕМЯЧИНСКОГО МЕСТОРОЖДЕНИЯ КАЛИЙНЫХ СОЛЕЙ
}

\section{Е.Ф. Ахлестина, Г.А. Московский \\ Отделение геологии НИИ ЕН СГУ \\ E-mail: MinihMG@info.sgu.ru \\ ${ }^{1}$ Геологический факультет \\ E-mail: MoskovskyGA@info.sgu.ru}

Авторы рассматривают состав пород, вскрытых скв. 13 на Гремячинском месторождении калийных солей, расположенном в Волгоградской области. Установлен разнообразный комплекс терригенных, кремнистых, карбонатных пород и их смешанных разностей, ритмично чередующихся по разрезу позднемеловых, палеогеновых, неогеновых и четвертичных отложений. Восстанавливаются условия их формирования в морских бассейнах, развитие которых на протяжении этого длительного времени связывается с периодическим проявлением тектонических событий как глобального масштаба, так и регионального характера.

Ключевые слова: калийная соль, Гремячинское месторождение, Волгоградская область, литология, седиментация, палеогеография.

\section{Mesozoic-Cenozoic Oversalt Deposits from the Gremy- achkinskoye Sylvinite Field}

\section{E.F. Acklestina, G.A. Moskovsky}

The authors consider compositions of the rocks penetrated with the Well No 13 in the Gremyachkinskoye sylvinite field, Volgograd Region. Varied complexes of terrigenous, ciliceous and carbonate rocks, alongside with their mixed varieties rhythmically alternate there over the Late Cretaceous, Paleogene, Neogene and Quaternary sections. Reconstructions have been made of their generation settings within marine basins; the basin evolution during that lengthy period used to be associated with periodic manifestations of tectonic events of both, global and regional scales.

Key words: sylvinite, Gremyachkinskoye field, Volgograd Region, lithology, sedimentology, palaeogeography.

Гремячинское месторождение калийных солей (сильвинитов) установлено на юге Приволжской моноклинали в так называемой преднадвиговой зоне, ограниченной на юге Северо-Котельниковским разломом [1]. В тектоническом строении зоны выделяют два структурных яруса. Верхний ярус включает толщу от четвертичных до нижнемеловых отложений со

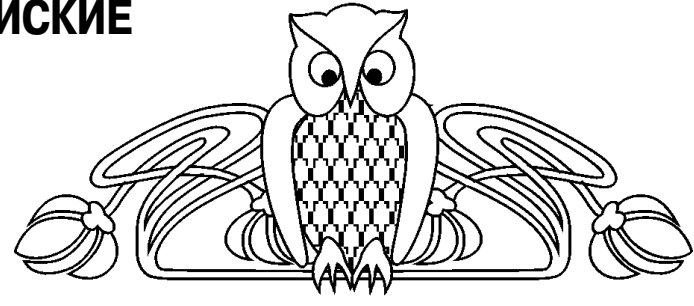

слабой дислоцированностью пород, пологим моноклинальным их погружением. Нижний ярус охватывает пермско-триасовые и каменноугольные отложения. Он характеризуется развитием локальных антиклинальных структур северо-западного простирания.

В работе авторы рассматривают наименее изученные надсолевые отложения верхнего структурного яруса, вскрытые в 2007 г. скв. 13 на Гремячинском месторождении (юг Приволжской моноклинали) в интервале 25,8-539,3м (рисунок). Они представлены терригенными, терригеннокремнистыми, терригенно-карбонатными породами позднемелового, палеогенового, неогенового и четвертичного возраста. Отложения нижнего мела и юры в данном разрезе отсутствуют. Ниже приводится описание этих отложений, основанное на результатах их комплексного минералогопетрографического изучения.

\section{Верхнемеловые отложения} (инт. 539,3-310 м)

Сеноман (инт. 539,3-501 м) представлен песками глауконитово-кварцевыми светлозеленовато-серыми мелко-, среднезернистыми. Кварц (80-85\%) присутствует в виде различно окатанных зерен размером 0,04-0,52 мм, иногда кавернозных, трещиноватых. Трещинки заполнены глауконитом. Последний составляет 10-15\%. Зерна его имеют различных тонов зеленую окраску, неправильные округлые очертания, микроглобулярное строение. Размер изменяется в пределах 0,04-0,12 мм. Отмечаются редкие частицы микроклина, плагиоклазов, обломки кремней кварц-халцедонового состава, кианит.

Турон-коньяк (инт. 501,9-464м) сложен литологически монотонной толщей мелоподобных почти белых тонкодисперсных известняков со слабовыраженными следами биотурбации, состоящих практически нацело из биогенного (кокколитового) пелитоморфного кальцита с беспорядочно рассеянными включениями фрагментов фораминифер, кальцисфер, редких алевритовых 


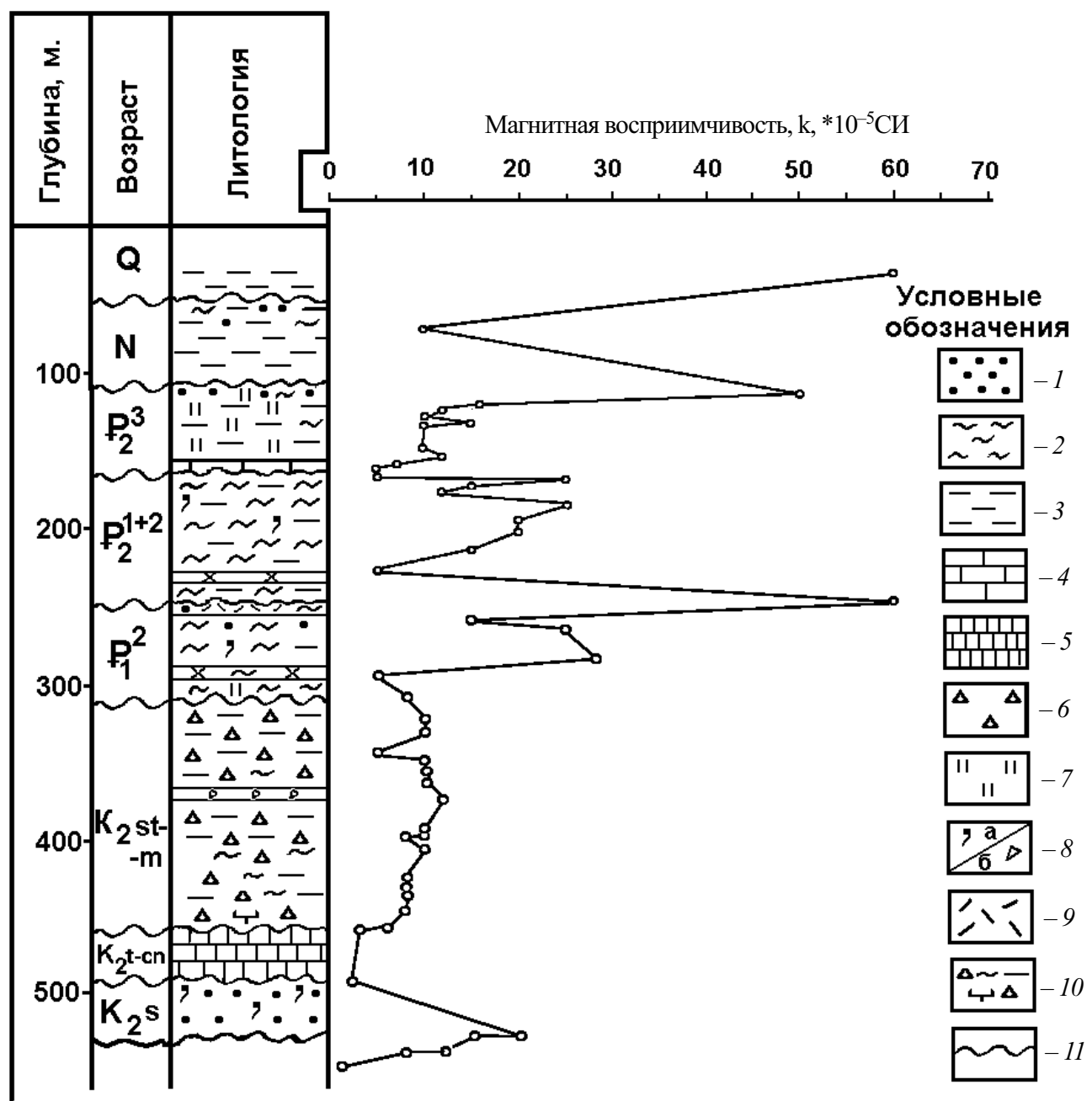

Разрез надсолевых мезозойско-кайнозойских отложений, вскрытых скв. 13 на Гремячинском месторождении калийных солей: 1 - пески, песчанистость; 2 - алевролиты, алевриты, алевритистость; 3 - глины, глинистость; 4 - известняки; 5 - мел; 6 - силициты опоковидные; 7 - диатомиты; 8 - (a) глауконит, (б) губки; 9 - вулканокластика; 10 - смешанный известково-алевритовоглинисто-кремнистый литотип, 11 - несогласное залегание пород

зерен кварца, чешуек мусковита, вкраплений пирита, углистых частиц.

Сенон (сантон-кампан-маастрихт) (инт. 464-310 м) представлен алевритово-глинистокремнистой группой смешанных двух-, трехкомпонентных пород с различными количественными соотношениями породообразующих компонентов. С некоторой долей условности выделяются следующие литотипы, ритмично чередующиеся между собой: алевролиты (гл. 310 м, 354,4 м, 364 м, 411,8 м), глины кремнистые (силицито-глины гл. 325 м и 333,8 м; глино-силициты - гл. 368,8 м, 374,4 м, 398,4 м, 404,9 м), силициты (гл. 347,2 м, 402 м, 433,2-464,8 м), песчаники (гл. 378,7 м). Это толща светло- и темно-серых, в основном тонкодисперсных пород неравномерно алевритистых, известковых, слюдистых, различных по плотности, крепости, неслоистых, с неровным до раковистого изломом, с редкими включениями известковых органических остатков.
Смешанный состав этих пород отражается и в гранулометрическом спектре, и в минеральном составе. Ни одна из выделенных гранулометрических фракций не является породообразующей. Обычно преобладают пелитовая $(<0,01$ мм - от $36,7 \%$ на гл. 357,7 м до 53,8\% на гл. 325,7 м), тонкоалевритовая (0,05-0,01 мм - от $12,87 \%$ на гл. 354,4 м до 26,78\% на гл. 310 м) или крупноалевритовая фракции (0,1-0,05 мм до 36,2\% на гл. 354,4 м). Минеральный состав алевритового материала представлен бесцветными угловатыми и полуокатанными зернами кварца, полевых шпатов, слюдами, глауконитом, редкими акцессориями. Тяжелые фракции обычно насыщены пиритом (от 51,8\% на гл. 325,7 м до 67,3\% на гл. 357,7 м) при практически постоянном присутствии глауконита (1-3\%), фосфатов (до 3\%). Кремнезем здесь тонкой наноструктуры опал-кристобалитового состава с фрагментами радиолярий различной степени сохранности, часто с замещением выщело- 
ченных полостей цеолитами. Глинистое вещество имеет в основном монтмориллонитовый состав, реже смешанно-слойный иллит-смектитовый. Прослоями отмечается примесь известкового кокколитово-фораминиферового материала, иногда значительная (25-30\% на гл. 347,2 м). Редко встречаются включения известковых золотистых водорослей (гл. 398,4 м), фосфатов (гл. 402 м, 374,4 м).

Ключевым прослоем является песчаник глауконитово-кварцевый с губками (губковый горизонт) (гл. 378,7 м). Песчаник имеет поликомпонентный состав. Значительную часть породы составляют реликты губок, различные по форме, размеру и составу (опаловые, кварцхалцедоновые). Пятнистые, гнездовидные скопления образуют цеолиты в виде мельчайших (10-20 мкм) кристалликов, заполняющих полости породы. Встречаются отдельные зерна кварца, полевых шпатов, глауконита часто с примазками мелких кристалликов соли (?), заполняющей и приконтактовые зоны зерен с матриксом породы известково- (кокколитово)-глинисто-кремнистого состава (гл. 378,7 м, 347,2 м). В некоторых участках породы пигментированы органическим (сапропелито-гуминовым) темным непрозрачным веществом. К ним приурочены вкрапления пирита, углистых частиц, углефицированных растительных остатков (гл. 374,4 м, 368,8 м, 354,4 м, $310 \mathrm{M})$

Однообразный литологический состав этой части меловых отложений, неполнота охарактеризованности разреза керном затрудняют расчленение их по ярусам. С относительной долей условности, опираясь на ритмичность строения алевритово-глинисто-кремнистой толщи, наличие отдельных реперных горизонтов, колебание магнитной восприимчивости (см. рисунок), выделяется четыре ритмопачки (снизу-вверх): 465,5411,0 м, 404,9-378,7 м, 378,7-331 м, 331-310 м.

Формирование этих осадков происходило в относительно спокойных условиях седиментации в морских бассейнах субокеанического типа, благоприятных для пышного развития 3о0- и фитопланктона [2].

\section{Палеоген (инт. 293,5-111,5 м)}

Палеогеновые отложения залегают на верхнемеловых породах с большим перерывом.

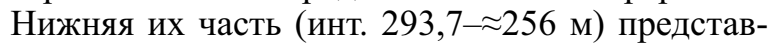
лена песчано-алевритовой толщей. Выделенные литотипы - песчаник глауконитово-кварцевый (гл. 293,7 м) с кремнистым пленочным цементом, песчаник кварцево-глауконитовый (гл. 283,9 м) с кальцит-ангидритовым цементом, алевролит глинистый (глино-алевролит (гл. 262,8 м) и алевролит песчаный, глауконитово-кварцевый (гл. 256 м) характеризуются темно-серой и серой окраской, неравномерным распределением исходного породообразующего материала, что обусловливает различную плотность, крепость пород, выделение соответствующих литотипов. Слабоотсортированный песчано-алевритовый материал представлен в основном зернами кварца, содержание которого изменяется от $30-35 \%$ до $40-45 \%$, и глауконита, образующего иногда пятнистые скопления. Роль цемента выполняет глинисто-кремнистое вещество. При этом кремнезем обычно полигенный (пленочный алюмокремнистый и кремниевый гидрогель, органогенный опал-халцедоновый по губкам), характерный для опоковидных силицитов палеоцена. Глинистое вещество имеет преимущественно монтмориллонитовый состав, участками образует небольшие уплотнения с субпараллельной ориентировкой отдельных чешуек (гл. 262,8 м). Некоторое исключение составляет песчаник кварцево-глауконитовый (глауконитит) (гл. 283,9 м), в котором глауконит (40-45\%) и кварц (30-35\%) «плавают» в различно окристаллизованном кальцит-ангидритовом матриксе.

Своеобразие этого песчаника подчеркивается и повышенной магнитной восприимчивостью. Залегание песчаника в основании палеоцена позволяет принять его за определенный рубеж в смене условий седиментации, связав процесс его формирования некоторой стабилизацией осадконакопления, активной глауконитовой минерализацией и «проработкой» отложившихся осадков (пород) солевыми растворами.

Завершающим прослоем нижней части палеогеновых отложений является известняк алевритистый (гл. 244 м). Это серая порода довольно плотная, крепкая, массивная, в составе которой породообразующим компонентом является различно окристаллизованный кальцит (60-65\%), участками сферолитового строения и часто со структурой замещенных минералов (кварца, полевых шпатов, слюд, вулканокластов). Гнездовидные скопления образует ангидрит (10-15\%). На фоне этой массы неравномерно распределены алевритовые зерна перечисленных выше минералов со следами разъедания кальцитом. Среди вулканокластов прослеживаются обломки кислого и базальтового стекла. Довольно часто наблюдаются зеленые округлые и лопастные зерна глауконита (3-5\%) размером 0,05-0,12 мм агрегатного строения, вкрапления пирита (2-3\%), иногда заполняющего полости редких органических остатков, углистые включения, углефицированные растительные обрывки тканей, стеблей, клеточные пустоты которых иногда заполнены кальцитом. Именно с этим интервалом связано самое высокое значение магнитной восприимчивости, установленное в изученной надсолевой части разреза Гремячинского месторождения. Описанный известняк аналогичен ранее описанному известковистокремнистому туффиту, залегающему в толще позднепалеоценовых-вешенских диатомитов в районе Нижнего Чира [3, 4]. Образование известняка связывается с активизацией тектонических движений в конце позднего палеоцена - начале 
раннего эоцена, сопровождавшихся проявлением вулканизма и гидротермальной деятельности.

Расположенная выше по разрезу глинистоалевритово-песчаная толща (инт. 222,2-168 м) характеризуется пятнисто-прожилково-линзовидным распределением породообразующих компонентов. Среди них выделяются следующие литотипы: песчаники алевритистые (гл. 222,2 м) и алевритовые (гл. 209 м), алевролиты (гл. 196,9 м и $179,6-170,6$ м) и глины (168 м).

Песчаники отличаются слабой сортированностью терригенного материала, неравномерной плотностью, рыхлостью, комковатой текстурой и практически мономинеральным кварцевым составом (до 80 - 90\%). Полевые шпаты составляют 3,4-8,1\% (соответственно гл. 209 м и 222,2 м), глауконит - 4,7-9,5\% легкой фракции. В тяжелой фракции значительно повышается содержание титанистых минералов (ильменита до 36,5-36,9\%; рутила $-4,8-6,0 \%$; сфена $-2,3-2,9 \%$; лейкоксена до $14,1 \%$ ) и циркона - $15,3-17,9 \%$, а также турмалина 2,9-3,6\% и граната - 6,9-18,0\%. Матрикс песчаников представлен небольшим количеством глинистого гидрослюдистого вещества (5-10\% по шлифу), обволакивающего обломочные зерна. Межзерновое пространство остается в основном полым. Лишь отдельные участки заполнены мелкими кристаллами цеолитов (гл. 209 м) и пиритом.

Многие зерна кварца (особенно крупные) расположены в «рубашке» мелких ромбовидных кристаллов соли (?) с показателем преломления < 1,535 и серой интерференционной окраской.

Алевролиты глауконитово-кварцевые зеленовато-серые тонкозернистые довольно плотные, но некрепкие (гл. 196,9 м, 188,8 м, 179,6 м) и рыхлые (гл. 170 м) с комковатой текстурой. В их гранулометрическом составе преобладают алевритовые фракции (тонкоалевритовые - изменяются в пределах 4,96-51\%; крупноалевритовые - от 7,2 до $67,2 \%$, гл. 170 м) и пелитовые (от 15,48 до 37,64\%) фракции. Песчаные мелкозернистые частицы составляют 3,72-11\%, более крупные единицы и доли процента. В минеральном составе мелкой фракции преобладают кварц (36,5-52,5\%) и глауконит $(10,4-44,5 \%)$. Значительно содержание агрегатов глинистого, кремнисто-глинистого состава (до 25,8\% гл. 196,9 м). Полевые шпаты составляют от 6,8 (гл. 170м) до 8,2\% (гл. 188,8 м). В долях процента встречаются мусковит, хлорит, фосфаты, опал (обрывки диатомей). Среди минералов тяжёлой фракции в наибольшем количестве отмечаются чёрные рудные ильменит - магнетит $(13,4-40,2 \%)$ и пирит $(4,7-57,9 \%)$, а также циркон $(5,2-10,5 \%)$, рутил $(1,8-3,6 \%)$, эпидот (до $8,6 \%$ гл. 170 м), гранаты (до 9,0\% гл. 188,8 м), лейкоксен $(3,9-7,9 \%)$. Единицы и доли процента составляют турмалин, кианит, силлиманит, ставролит, пироксены, амфиболы, сфен, анатаз, мусковит, хлорит, фосфаты, глауконит, хлоритоид и др. Роль матрикса в алевритах выполняет глинистое вещество, микрозернистое и тонкочешуйчатое, монтмориллонит-гидрослюдистого состава, слабо поляризующее и пигментированное органическим (сапропелит-гуминовым) веществом с вкрапленностью пирита, углистых частиц, углефицированных и иногда пиритизированных растительных остатков. Участками глинистое вещество образует прожилково-линзовидные уплотнения с субпаралельной ориентировкой отдельных чешуек. Предполагается примесь колломорфного кремнезёма (кремниевого, алюмокремниевого гидрогеля), цеолитов, проявляющихся (гл. 196,9 м) в виде мельчайших (до 0,02 мм) кристалликов. Характер цементации контактово-поровый. Цементация непрочная, прослоями (гл. 170 м) практически отсутствует. Структуры пелитово-алевритовые.

Незначительный пик повышения магнитной восприимчивости отмечается на гл. 179,6 м, обусловленный, по-видимому некоторым увеличением железосодержащих минералов.

Завершается разрез этой пачки пород глиной (гл. 168м.) светло-серой алевритистой тонкодисперсной, сложенной в основном тонкочешуйчатым монтмориллонитом (65-70\%) с субпараллельно ориентированным расположением глинистых чешуек и содержащей примесь кальцита (10-15\%) в виде реликтов фораминифер. Алевритовый материал (15-20\%) представлен, главным образом, бесцветными угловатыми и полуокатанными зернами кварца (10-15\%), полевыми шпатами (3-4\%), глауконитом (3-5\%). По данным гранулометрического анализа, в глине выделяются пелитовая фракция (62,9\%), тонкоалевритовая $(9,4 \%)$, крупноалевритовая $(13,44 \%)$, мелко- $(6,4 \%)$ и среднезернистая (6,84\%) песчаные фракции. Согласно литологическому анализу в минеральном составе песчаноалевритовой фракции (0,25-0,01 мм), выделенной из глины, в легкой фракции преобладают обломки породы (56,8\%) глинистого состава и кварц (24,5\%); в тяжелой - пирит $(32,6 \%)$ и черные рудные (магнетит, ильменит) $(22,5 \%)$. В заметном количестве отмечаются гранаты (13,2\%), циркон $(6,5 \%)$, кианит (4,5\%), лейкоксен $(7,4 \%)$, сфен $(1,5 \%)$.

Глина этого интервала является, по-видимому, переходным слоем к карбонатной толще мелоподобных известняков. Образование ее происходило при некоторой стабилизации осадконакопления в морских бассейнах в период смены регрессивной фазы (средний эоцен) трансгрессивной (поздний эоцен).

Известняки белые мелоподобные (инт. 162,4 - 155,7 м), залегающие выше, сложены практически нацело органогенным кальцитом (до 80-95\%) - кокколитовым и фораминиферовым шламом с незначительной примесью в нижней части глинистого (монтмориллонита) (10-15\%) и алевритового (10-15\%) материала.

Разрез палеогена завершается толщей сероцветных тонкодисперсных глинисто-кремнистых пород (инт. 151-111,5 м), среди которых выделяются диатомито-глины, глино-диатомиты и диатомиты глинистые, алевритистые. Породообразую- 
щими их компонентами являются органогенный опаловый кремнезем (реликты диатомовых водорослей, силикофлагеллат, редких радиолярий) и глинистое вещество (монтмориллонит, примесь микроглобулярного глауконита), количественные соотношения между которыми изменяются в широких пределах. Участками отмечается примесь алевритового материала (кварца, глауконита, полевых шпатов, слюды) в виде рассеянной беспорядочно вкрапленности (гл. 122 м, 125,6 м) или линзовидных, пятнистых скоплений (гл. 113,4 м, 117,9 м). В гранулометрическом спектре пробладает пелитовая фракция $(<0,01$ мм $)$ - от 49,78 до $64,88 \%$. Содержание тонкоалевритовой фракции $(0,05-0,01$ мм) изменяется в широких пределах $(11,1-32,1 \%)$, крупноалевритовой - 9-15,88\%. Количество песчаных частиц преимущественно мелко- и среднезернистых незначительно (от долей до 7-8\%). В минеральном составе песчаноалевритовой фракции среди легких минералов характерно преобладание или значительное содержание обломков пород глинисто-кремнистого состава агрегатного строения, часто с включениями опаловых обломков диатомовых водорослей, силикофлагеллат. Последние присутствуют также в виде отдельных опаловых частиц $(6,9 \%$ - гл. 113,4 м или до 12,5\% - гл. 125,6 м). Кварц составляет обычно 18,5-52,1\%. В тяжелой фракции преобладают пирит (от 19,4 до 83,7\%) и магнетит (до 50\% - гл. 123 м), обусловивший повышение магнитной восприимчивости.

Формирование диатомитов происходило в основном в несколько углубленной части морского бассейна с относительно спокойными условиями седиментации фитопланктона и глинистого материала, периодически разбавляемого различным количеством алевритового [2].

Песок (гл. 112,5 м), залегающий в кровле диатомитов, кварцевый разнозернистый с преобладанием крупнозернистой фракции $(51,0 \%)$ буровато-светло-серый с крупными известковыми включениями (до 3 мм) и кремнистыми слабосцементированными комками. Песок плохо отсортирован. Наряду с крупными зернами определяются все размерные фракции, особенно значительно содержание пелитовой фракции $(24,5 \%)$ и мелкозернистой песчаной $(15,6 \%)$. В минеральном составе песка преобладают различно окатанные зерна кварца (55-60\%), иногда трещиноватые со следами растворения. Относительно редко отмечаются обломки опоковидных пород (5-10\%), мела (2-3\%), железистых песчаников (1-2\%), углефицированные и пиритизированные обрывки растений (5-10\%), полевые шпаты (7,7\% легкой фракции). Межзерновое пространство частично заполнено пелитовым глинисто-кремнистым материалом с реликтами диатомовых водорослей (опал составляет 3,3\% легкой фракции), выполняющим и роль цемента песчаного материала.

Образование песка происходило, вероятно, в прибрежной зоне морского бассейна (зоне пере- мыва и переотложения осадков). Его залегание в толще тонкодисперсных кремнистых глин (диатомитов глинистых) связано, по-видимому с перерывом в осадконакоплении на границе палеогена и неогена и внедрением в толщу диатомитов турбидными потоками.

\section{Неогеновые отложения}

Неогеновые отложения (гл. 105,4 м) представлены глиной алевритовой слабоизвестковистой, серого цвета плотной однородной неслоистой с мелкими углистыми включениями. Породообразующее глинистое вещество тонкодисперсное, в основном гидрослюдисто-монтмориллонитового состава. Отмечается примесь кремнистого вещества в виде слабополяризующихся сгустков гидрогеля и реликтов диатомовых водорослей, биогенного кальцита со следами растворения. В гранулометрическом спектре этой породы преобладает пелитовая фракция (67,21\%). Алевритовые тонко- и крупнозернистые фракции составляют $18,38 \%$ и 8,72\% соответственно, песчаные фракции - в сумме 5,7\%. Среди тяжёлых минералов в составе породы преобладают чёрные рудные (ильменит и магнетит) - 58,6\%. Характерно также появление пирита (4,1\%). Видимо, с существенным содержанием рудных минералов в этой породе связан второй пик магнитной восприимчивости. Исходя из приведённых данных, можно предполагать, что формирование описываемого типа отложений происходило в относительно спокойных стабилизированных условиях седиментации морского бассейна.

\section{Четвертичные отложения}

Четвертичные отложения (инт. 25,8-60 м) представлены глинами алевритовыми, песчаноалевритовыми известковистыми, суглинками песчано-алевритовыми.

Глина алевритовая (гл. 25,6 м) светлокоричневая с красноватым оттенком, участками известковистая неслоистая с комковатой текстурой, пигментированная гидроокислами железа и марганца. Глинистое вещество грубочешуйчатое и волокнистое с примесью пелитоморфного кальцита в виде переотложенных фрагментов кокколитового ила, мергелевидных и мелоподобных пород. Пелитовая фракция составляет здесь $68 \%$, алевритовая тонкозернистая $(0,05-0,01 \mathrm{MM})$ $-21,2 \%$, крупноалевритовая (0,1-0,05 мм) - 9,3\%, песчаные фракции - доли и единицы процента. В минеральном составе преобладают обломки глин агрегатного строения, составляющие 71,6\% легкой фракции, кварца - 16,5\%, полевых шпатов - 7,3\%. Для этой породы характерно присутствие барита (до 23\% тяжелой фракции), что свидетельствуюет об опреснении вод бассейна седиментации в период накопления описываемой глины.

Глина (гл. 45,5 м) светло-серая песчанистоалевритовая, слабо известковистая имеет неравномерно сгустковую структуру, обусловленную, 
по-видимому, многократной переработкой породы почвенными процессами, в результате которых глинистое вещество неоднородное - от грубочешуйчатого волокнистого до колломорфного. Породообразующей здесь также является пелитовая фракция $(65,24 \%)$. Алевритовые фракции составляют $12,14 \%$ (тонкоалевритовая 0,05-0,01 мм) и 8,64\% (крупноалевритовая 0,1-0,05 мм). Песчаные фракции в сумме составляют 13,98\%. В минеральном составе этой породы увеличилось количество глинистых агрегатов (до 87,6\% легкой фракции), титанистых минералов (ильменита $36,6 \%$, рутила $5,9 \%$, лейкоксена $7,5 \%$ ) и циркона (до 15,9\%), уменьшилось количество барита (до 5,7\%), но осадконакопление, по-видимому, происходило еще в зоне опресненного водоема.

Суглинок (гл. 60 м) песчано-алевритовый с известковыми и ангидритово-карбонатными стяжениями, с округлыми обособлениями («бобовинами») окислов марганца, с комковатой, брекчиевидной текстурой. Породообразующее глинистое вещество поликомпонентно по составу (гидрослюда, монтмориллонит, хлорит и др.) и различно по строению - от тонкодисперсной массы до волокнистой и крупночешуйчатой. Отмечается примесь известкового (кокколитового) пелитоморфного материала и предполагается присутствие кремнистого вещества.

Согласно гранулометрическому анализу пелитовая фракция составляет $51,12 \%$, тонкоалевритовая - 10,92\%, крупноалевритовая - 21,4\%. Песчаные фракции в сумме присутствуют в количестве $16,56 \%$. Минеральный состав отличается значительным увеличением кварца (до 67\% легкой фракции), уменьшением глинистых агрегатов (до $17,9 \%$ ). В тяжелой фракции заметно увеличилось содержание лейкоксена (до 16,5\%). В виде единичных зерен отмечается барит. Наличие карбонатноангидритовых выделений в породе, возможно, связано с циркуляцией в ней сульфатно-карбонатных растворов. Предполагается делювиальная природа отложений этой части разреза.

Проведённые исследования керна скв. 13 на Гремячинском месторождении позволили сделать следующее:

1. Уточнить состав пород.

2. Выделить характерные литотипы позднемеловых, палеогеновых, неогеновых и четвертичных отложений.

3. Установить два характерных рубежа: на гл. 378,7 м губковый горизонт в алевритовоглинисто-кремнистой толще позднего мела и на гл. 244 м - известняк туфогенный с вулканокластикой и с ангидритом. Последний отражает ряд седиментационно-литогенетических процессов, происходящих в осадке под влиянием тектоновулканической и гидротермальной деятельности на границе палеоцен-эоцена.

4. Рассмотренный комплекс пород позднего мела и палеогена представлен ритмично построенной толщей терригенных, карбонатных, крем- нистых отложений и их смешанных разностей. Формирование их происходило в морских бассейнах, развитие которых на протяжении этого длительного времени связано с периодическим проявлением тектонически обусловленных явлений как глобального масштаба, так и регионального характера (трансгрессии, регрессии). В трансгрессивные этапы акватории бассейнов приближались к субокеаническим, представляя шельф океана Тетис, с активной жизнедеятельностью планктонных фито- и зообиоценозов (кокколитофорид, фораминифер с известковой функцией в позднем мелу и палеогене, радиолярий в позднем мелу, диатомовых водорослей, силикофлагеллат в палеогене с кремниевой функцией).

Их пышному расцвету способствовали нормальные солевой и газовый режимы, обилие питательных веществ, теплые воды. Температуры вод позднемеловых и палеогеновых бассейнов испытывали небольшие колебания. Среднегодовые температуры, согласно изотопной палеотермометрии изменялись на юге Русской платформы, например, в бассейнах сантона в интервале $16,5-23,8^{\circ} \mathrm{C}$, эоцена $-26,6-28,2^{\circ} \mathrm{C}$. Обилие планктона в бассейнах способствовало биогенному осадконакоплению - карбонатных (известняков и мелов) и кремнистых (радиоляриевых в мелу, диатомитов - в палеогене) осадков обычно с примесью глинистого вещества в относительно глубоководных зонах бассейна.

5. В регрессивные этапы развития бассейнов акватории сокращались, моря мелели. Усиливался привнос терригенного материала, перемыв ранее отложившихся осадков, что обусловливало образование смешанных (терригенно-карбонатных, терригенно-кремнистых) и терригенных разностей отложений. Переходные рубежи, особенно регрессивно-трансгрессивные, отчетливо фиксируются в разрезе литологическими изменениями и (или) перерывами.

\section{Библиографический список}

1. Свидзинский С.А., Музалевский М.М., Ковальский Ф.И. Гремячинское месторождение сильвинитов // Новые данные по геологии соленосных бассейнов Советского Союза. M., 1986. C. 204-219.

2. Ахлестина Е.Ф., Иванов А.В., Первушов Е.М. Роль кремниевых организмов в осадконакоплении в позднемеловых и палеогеновых бассейнах Поволжья // Тр. НИИГеол. СГУ. Нов. сер. Т. 7. 2001, С. 19-30.

3. Ахлестина Е.Ф. Курлаев В.И. Эоценовые пепловые отложения Саратовского и Волгоградского Поволжья // Вопросы геологии Южного Урала и Поволжья. Саратов, 1988. Деп.ВИНИТИ № 7068 - В. 88. С. 19-130.

4. Муравьев В.И., Цеховский Ю.Г., Ахлестина Е.Ф., Бабушкин А.Д., Каледа К.Г. Вулканические пеплы базальтового состава из палеоценовых отложений Южного Поволжья // Литол. и полезн. ископаемые. 1997. № 3. C. 327-330. 